\title{
A regulamentação do Homeschooling no estado da Califórnia (EUA): subsídios para reflexão do movimento no Brasil
}

\section{Tauane Oliveira dos Reis*, Luciane Muniz R. Barbosa}

\section{Resumo}

Em um contexto de continuidade de pesquisa sobre homeschooling/educação domiciliar, estabelecendo um paralelo entre o cenário dos Estados Unidos da América (EUA) e o Brasil, esta pesquisa tem como objetivo analisar a regulamentação do homeschooling no estado da Califórnia, de modo a refletir sobre o movimento da educação domiciliar na atual conjuntura brasileira. A pesquisa fez uso de metodologia qualitativa, com procedimentos que consistiram em levantamento bibliográfico e de dados oficiais dos dois países. Desde a década de 1990, a prática do homeschooling é legal em todo o território dos EUA, onde cada estado apresenta um tipo e nível de regulamentação. A Califórnia classifica-se entre os estados com baixa regulamentação do homeschooling, o que significa que não há muitas exigências para que as famílias passem a ensinar os filhos em casa. Contudo, notícias demonstraram que as tentativas de maior regulamentação ao longo das últimas três décadas são frequentes, o que leva as famílias educadoras a envolverem-se em conflitos judiciais por motivos diversos. No Brasil, a educação domiciliar aproxima-se da sua legalização, visto ter sido proposta de governo do atual presidente da República que apresentou um projeto de lei estipulando os requisitos mínimos para a prática desta modalidade no país. Considerando tais informações e as diferenças dos contextos dos dois países, associar os eventos do cenário brasileiro às conflituosas experiências californianas, permite conjecturar os muitos desafios do movimento em prol da educação domiciliar no Brasil, para além do processo de regulamentação.

Palavras-chave: homeschooling; regulamentação; Califórnia.

\section{Introdução}

O homeschooling/educação domiciliar pode ser compreendido como a prática em que as famílias retiram seus filhos da escola regular para ensiná-los em casa ou em ambientes que considerem mais apropriados. Referência nesta modalidade de ensino, os Estados Unidos da América (EUA) têm a prática regulamentada desde a década de 1990, com diferentes níveis de regulamentação em cada estado. Apesar desse histórico, a Califórnia se destaca por ser um local onde as famílias praticantes do homeschooling ainda enfrentam embates com o governo local.

No Brasil, o movimento em prol da regulamentação da educação domiciliar tem crescido nas últimas décadas (BARBOSA, OLIVEIRA, 2017), tendo a prática sido julgada pelo Supremo Tribunal Federal (STF). Entre os cenários dos EUA e o Brasil, esta pesquisa tem como objetivo analisar a regulamentação do homeschooling no estado da Califórnia, de modo a refletir sobre esse movimento na atual conjuntura brasileira.

\section{Resultados e Discussão}

$\mathrm{Na}$ classificação elaborada pela Home School Legal Defense Association (HSLDA) quanto ao nível de regulamentação do homeschooling nos EUA, a Califórnia é considerada um estado com moderada e baixa regulamentação. Segundo informações do California Department of Education (CDE), oferece diferentes opções de adesão ao homeschooling: por meio de matrícula em escola privada existente; de carta pública ou programa de estudos independente; de abertura de escola privada em casa; entre outros.

A HSLDA também apresenta diversos casos de famílias praticantes do homeschooling na Califórnia que enfrentaram confrontos judiciais por diferentes motivos que envolvem: benefícios monetários da previdência social; denúncias de abusos e negligência; atuação questionável da polícia e da assistência social com famílias homeschoolers; e, principalmente, o toque de recolher diurno, que prevê que crianças e adolescentes em idade escolar estejam fora das ruas no período de funcionamento das escolas. Tais ações têm demandado mudanças na legislação que regulamenta a prática do homeschooling, impactando as famílias educadoras.

No Brasil, o STF decidiu, em 2018, pela inconstitucionalidade da prática da educação domiciliar, por falta de lei que a regulamente. Em janeiro de 2019, o atual presidente da República apresentou a educação domiciliar como uma das metas prioritárias de seu governo e, em abril deste ano, assinou um projeto de lei visando à regulamentação da prática e o encaminhou ao Congresso Nacional.

\section{Conclusões}

Milhares de famílias brasileiras realizam o homeschooling e lutam cada vez mais pela sua legalização. Para além do contexto nacional, há, inclusive, iniciativas municipais de projetos de lei autorizando a prática.

A experiência na Califórnia evidencia que, embora a prática torne-se legal, há muitos desafios e um longo debate sobre a quem pertence de fato $o$ direito à educação das crianças e adolescentes.

\section{Agradecimentos}

Ao auxílio financeiro do Programa Institucional de Bolsas de Iniciação Científica (PIBIC).

BARBOSA, L. M. R.; OLIVEIRA, R. P. Dossiê: Homeschooling e o Direito à Educação. Pro-Posições (Unicamp). , v.28, 2017.

California Department of Education/CDE. Disponível em: https://www.cde.ca.gov/sp/ps/homeschool.asp. Acesso em: 09 jul. 2019 Home School Legal Defense Association/HSLDA. Disponível em: https://hslda.org/content/ Acesso em: 09 jul. 2019 